\title{
The relocation of the village of Arkwasiye in the Simien Mountain National Park in Ethio- pia: an intervention towards sustainable development?
}

\author{
Tiru Berihun Tessema, Michael Jungmeier \& Michael Huber
}

Keywords: National Park, World Heritage, Ethiopia, relocation, protected area management, development co-operation, UNESCO

\section{Abstract}

The study analyses the effects of the relocation of the village Arkwasiye in the Simien Mountains National Park, a most spectacular landscape in the northern highlands of Ethiopia. The relocation was deemed necessary as just one component in a bundle of measures proposed by the UNESCO World Heritage Commission. In 2007 some 165 households were relocated voluntarily to the new village of Kayit. The socio-economic effects of the relocation were evaluated by carrying out on-site interviews with the residents. The results indicate that the relocated villagers are satisfied with the new infrastructures and social services. However, relocation has also brought certain disadvantages with far-reaching consequences for the everyday life of the villagers, and thus their livelihoods, as these have led to a considerable loss of earning opportunities and - against the aims of the relocation - to intensified grazing in the area. The authors discuss these results in the light of a recent global discussion on relocation for conservation purposes and come up with five recommendations. Close monitoring of key parameters is seen as a minimum requirement for such an undertaking.
Profile

Protected Area

Simien Mountain National Park

Mountain range

Simien Mountains

Country

Ethiopia

\section{Introduction}

If the management of protected areas is to be regarded as a continuous process of regional intervention, participation and change management (Jungmeier et al. 2010), the park authorities have to be permanently in charge of initiating, promoting, communicating and fostering processes designed to bring about the required changes. Most activities focus on adapting land-use regimes and resource policies in a park or its adjacent areas. Other than diversified strategies and tools, the resettlement of residents is a radical measure and therefore highly controversial. Global estimates range from 900000 to 14.4 million persons that have become whether voluntarily or not - displaced for conservation purposes (Geisler 2003, cited in UNEP 2008). The provocative and drastic description of conservation refugees (Dowie 2009) has shocked conservationists all around the world. Are conservationists sacrificing human welfare and well-being for the sake of what can be termed imperial conservation, as Dowie (2009) argues, or can relocation - under particular circumstances and assumptions - be a reasonable measure to improve land uses and the livelihoods of people? Or is relocation generally just another brick in the wall of the dilemma between biodiversity conservation and poverty reduction (Cernea \& Schmidt-Soltau 2003)?

The case study of Arkwasiye (Ethiopia), as presented in this paper, should be regarded as a small contribution to a global discussion of inherent importance (Cernea 2006, 2007; Coad et al. 2008; Lasgorceix \& Kothari 2009; Roe et al. 2003; Redford \& Fearn 2007; Schmidt-Soltau 2005; www.displacement.net).

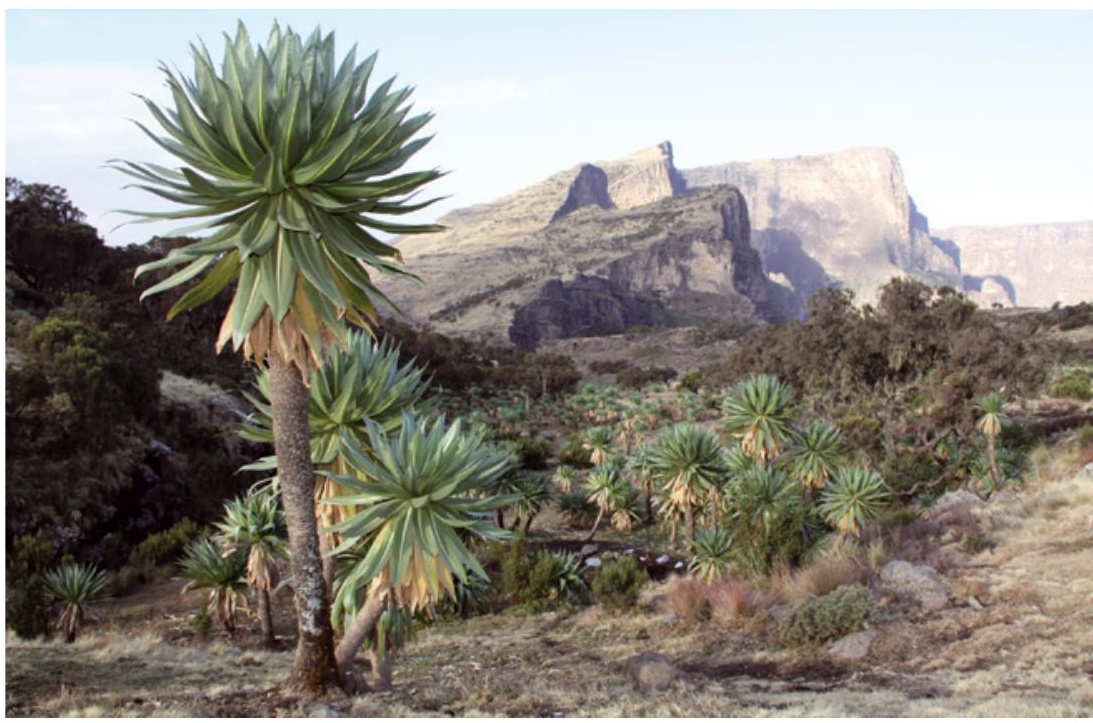

Figure 1 - Typical landscape of the northern Ethiopian highlands: the Simien Mountains. (C) M. Jungmeier

Arkwasiye was a settlement of some 165 households in the Simien Mountains National Park (SMNP, Ethiopia, see map: Figure 2), a most striking landscape with outstanding biodiversity assets (Keiner 2001; Hurni \& Ludi 2000). After discussions and once compensation schemes had been agreed, the inhabitants moved to the newly built village of Kayit, some two kilometres away as the crow flies. In the year 2000, a fact-finding mission led by national and international experts had proposed a realignment of park boundaries and the relocation of four villages (Gich, Islam Debir, Adarmaz, Muchila) from within the SMNP (Debonnet et al. 2006). A Joint WHC-IUCN reactive moni- 


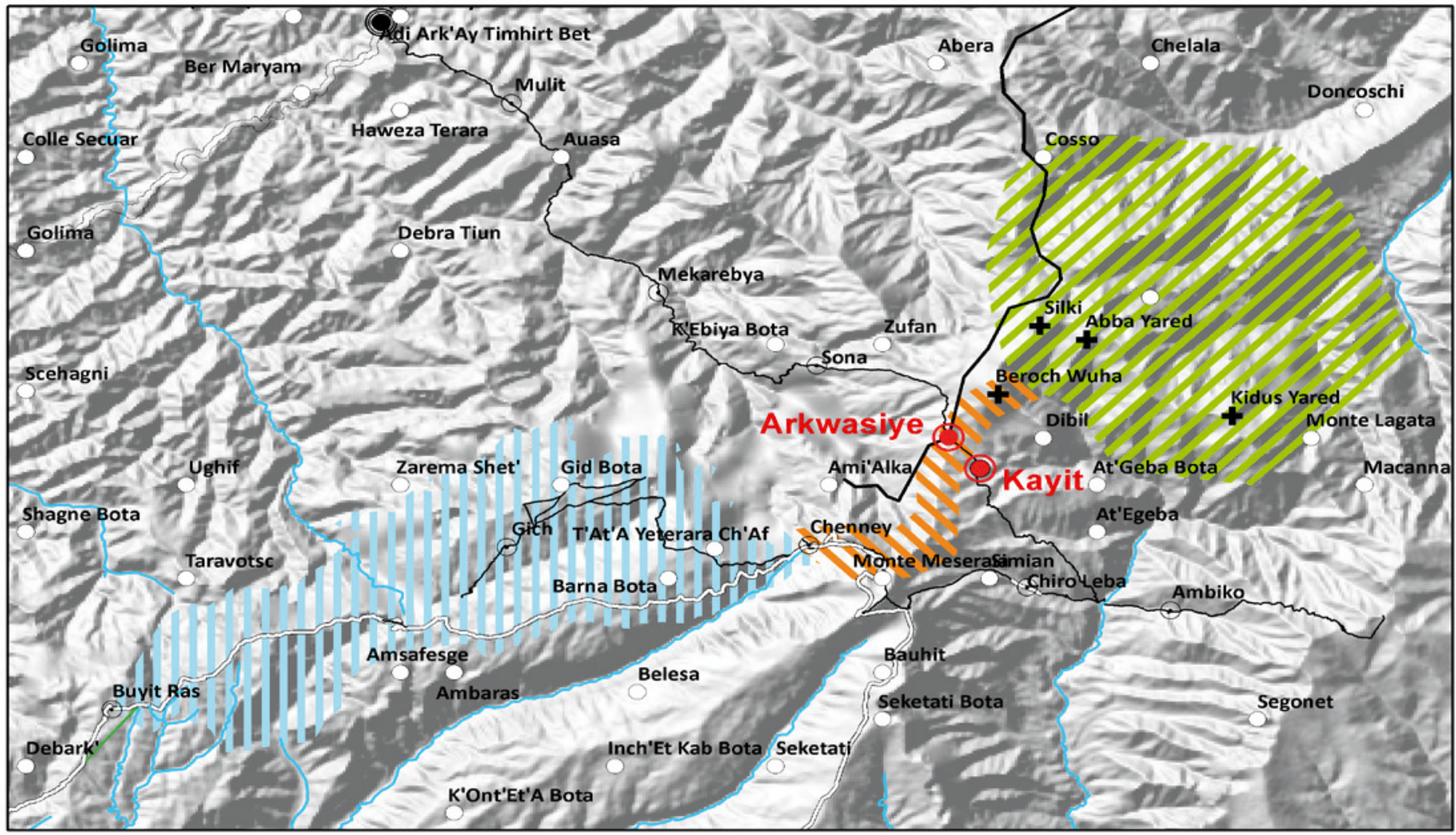

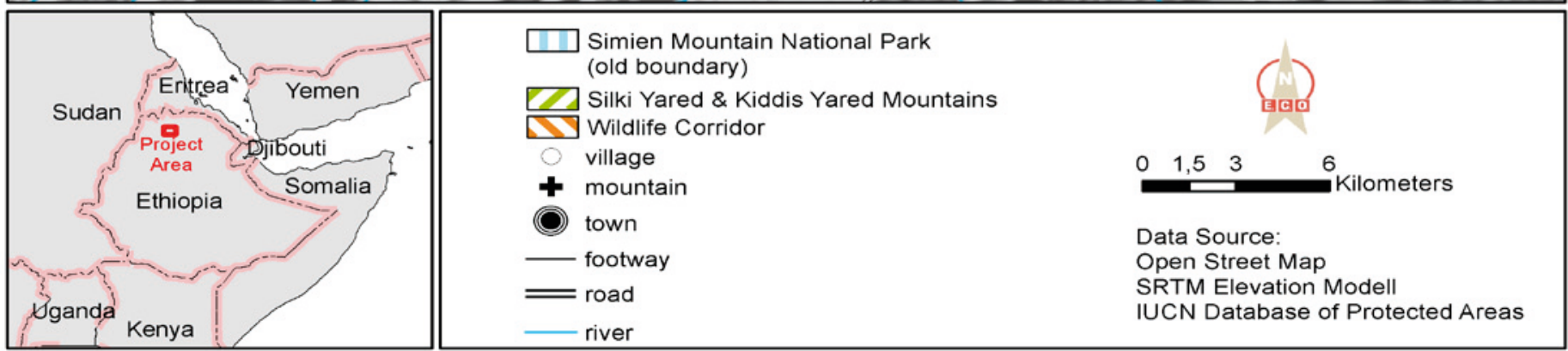

Figure 2 - Map of the project area, E.C.O. 2012.

toring mission in 2006 (Debonnet et al. 2006) recommended the Arkwasiye village should be relocated where it would no longer block the critical wildlife corridor. As indicated in Figure 2, the village was a problematic barrier for the intended and most relevant expansion of the park to the east. The report explicitly calls the village of Arkwasiye illegal (p. 19) and considers that the mission team was also informed that a win-win solution had finally been found for the problem of the Arkwasiye village (p. 11). In 2009, after the relocation had been completed, a joint mission by UNESCO and IUCN recognized considerable progress ... in restoring and enhancing the Outstanding Universal Values (OUVs) for which the park was inscribed in 1978 and in particular noted the relocation of Arkwasiye as a significant achievement which creates opportunities for the wildlife whilst improving the livelihoods of those who were relocated (UNESCO / IUCN 2009). The relocation was executed by the local national park administration with financial and technical support given by the Austrian Development Agency (ADA). The institutions involved seem to bear testimony to a cautious and thoughtful process. However, the relocation was to be evaluated some three years later in the context of a master thesis at Klagenfurt University (Tiru 2011).

\section{Research questions and methods}

Given that relocation is a highly sensitive matter, the authors do not intend to initiate an ethical or political discussion. The focus of the case study is strictly on the impacts of this relocation. The study focuses on the following research questions:

The economic dimension: is there any evidence to show in what way relocation has had any effects on the economic situation of the inhabitants and the households of former Arkwasiye, now Kayit? The social dimension: how do the village residents perceive and evaluate the changes in their personal, i.e. individual everyday life and community life?

The ecological dimension: does the relocation have any effects on the ecological situation, the land uses and the endangered wildlife? 
The findings presented in this paper are based on quantitative and qualitative interviews and workshops. There were numerous face-to-face interviews with local residents, representatives of the local communities, the park management and regional as well as local administrations (Tiru 2011).

Of 165 former Arkwasiye households, members of 64 households were interviewed, i.e. $39 \%$ of the total number of households. A breakdown of the sample of interviewees in terms of gender, age, household size, education and years spent in Arkwasiye is presented in Figure 3. There was not a single refusal to be interviewed and thus the response rate was $100 \%$.

In addition to the interviews, materials and literature were assessed and used for a plausibility check. Particular attention was given to feedback loops with those responsible for the management of the park. To gain an overview of the ecological situation after Arkwasiye was relocated, the old location was visited, together with different stakeholders and experts, to evaluate the ecological dimension (Tiru 2011).

Finally, at this point, a semantic aspect must be emphasized: A large number of words signify the physical dispossession of peoples from their lands: displacement, dislocation, eviction, exclusion and involuntary resettlement are routinely used (Redford \& Fearn 2007). We prefer the term relocation because it is used in official documents (e.g. Debonnet at al. 2006; UNESCO / IUCN 2009) and does not seem to have an ideological connotation. Also the spelling of toponyms and species is in accordance with the two said documents.

\section{Relocation - background and process}

Simien Mountains National Park (SMNP) is a prominent example of the Ethiopian national parks. Located in the North Gondar Zone of the Amhara Region, its territory covers the Simien Mountains and includes Ras Dashen (4430 m), the highest point in Ethiopia. The park was established in 1969 and, alongside Awash NP in Oromia, it is one of only two gazetted national parks in the country. USAID (2008) considers that the conservation of Ethiopia's biodiversity is an issue of global importance ... Threats to Ethiopia's biodiversity, tropical forests, and resource base can be broadly linked to the following categories: limited governmental, institutional, and legal capacity; population growth; land degradation; weak management of protected areas. Conservation International includes the Eastern Afromontane Biome, as represented by SMNP, in the list of the most endangered terrestrial ecoregions (Mittermaier et al. 2004). SMNP represents the typical situation of the developing country where a threat to ... biodiversity is serious and urgent action in policy and on the ground implementation is required (Institute of Biodiversity Conservation 2009; see also ÖBF 2009).

Hurni \& Ludi (2000) describe the SMNP as a representative landscape of the northern Ethiopian highlands, characterized by topographic ruggedness with steep escarpments - and with breath-taking beauty ... [it] has a rich

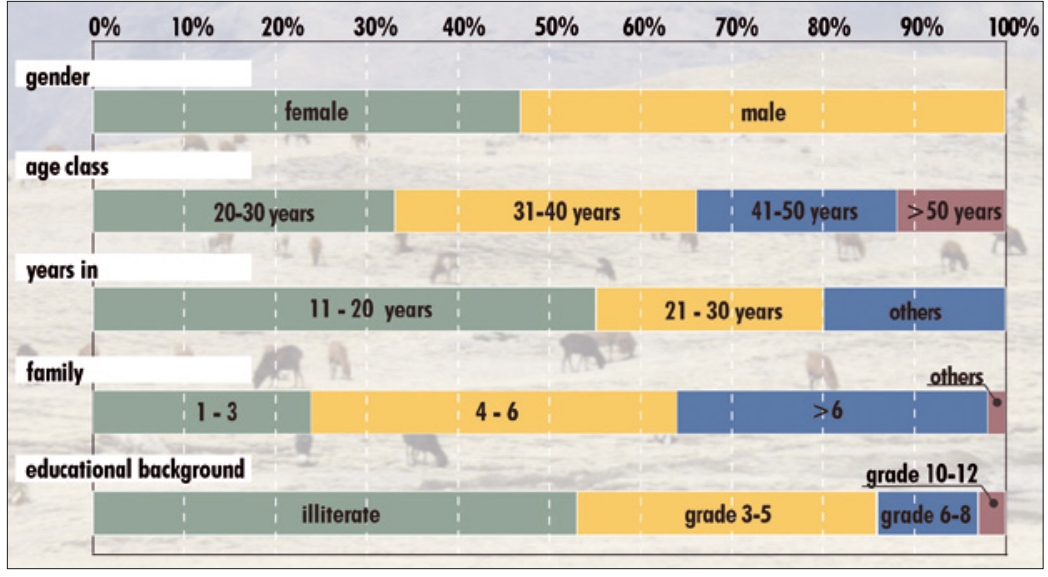

Figure 3 - Sample of interviewees (based on Tiru 2011).

natural biodiversity with altitudinal successions of fauna and flora and many endemic species of which the Walia ibex has become a national symbol. In their comprehensive monograph, Hurni \& Ludi (2000) provide an overview of SMNP and the development options of the region and its villages. However, over the past few years, further research has added to the picture of an area of outstanding importance for biodiversity (e.g. Puff \& Nemomissa 2005).

On account of its Outstanding Universal Values, the park was recognized as a World Heritage Site in 1978 by the UNESCO World Heritage Committee. As a late consequence of the civil war in the 1980s, which had led to the destruction of the infrastructure of the park, and thus, presumably, to a reduction in the number of Walia ibex, the site was included in 1996 in the List of World Heritage Sites in danger. The authorities responsible for the administration of the park were required to reorganize the management, as well as the park itself, to achieve the official removal of the park from the list of endangered sites. Debonnet et al. (2006) remark that there are no accurate estimates on how many people were included in the park at its creation in 1969. However it is clear that substantially more than half of the extent of the park. was under human use at the time of inscription. In 1979 . . 7 villages were relocated from the northern slopes of the escarpment. This forced resettlement resulted in tensions between the local communities and the park management authorities. However, the human impact on SMNP remained high. Consequently, based on diverse initiatives, the boundaries of the park were to be re-aligned to exclude villages and intensively used areas and to integrate ecologically valuable areas. The village of Arkwasiye happened to be located on a wildlife corridor between the old part of the park and the extended area of the Silki Yared and Kiddis Yared Mountains.

At that time, Arkwasiye village consisted of approximately 165 households. Originally, Arkwasiye had been an open air market place at a strategically important pass between the Meshaha and the Ansiya valleys. Situated at the crossing of old trading routes between Gonder, Mekelle, Axum and Lalibela, it was a place where mainly the surpluses from subsistence 


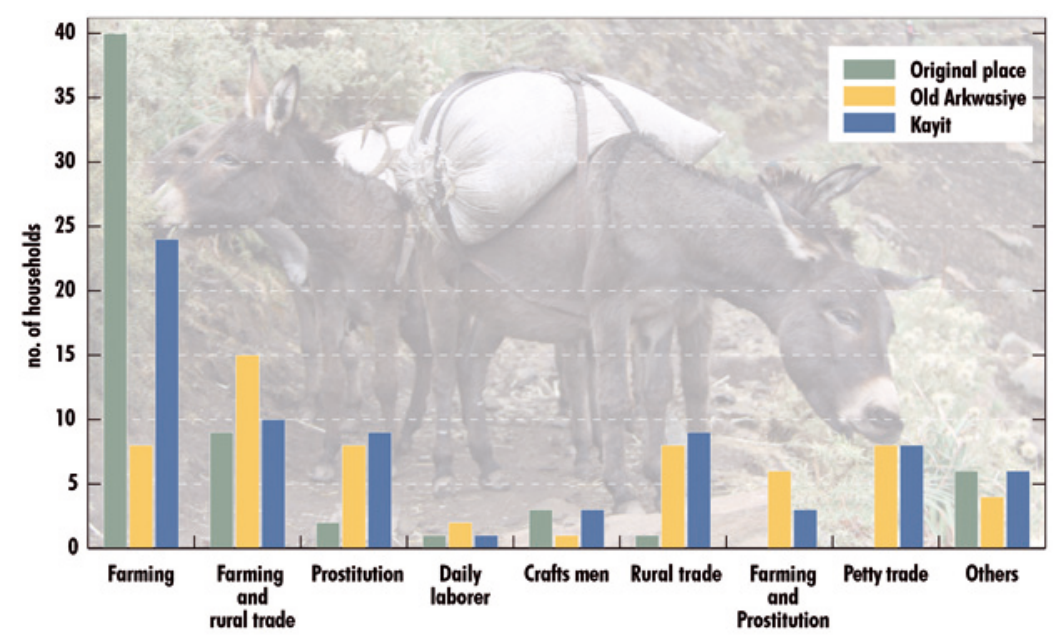

Figure 4 - Changing patterns of livelihood (based on interviews in 64 bouseholds; Tiru 2011).

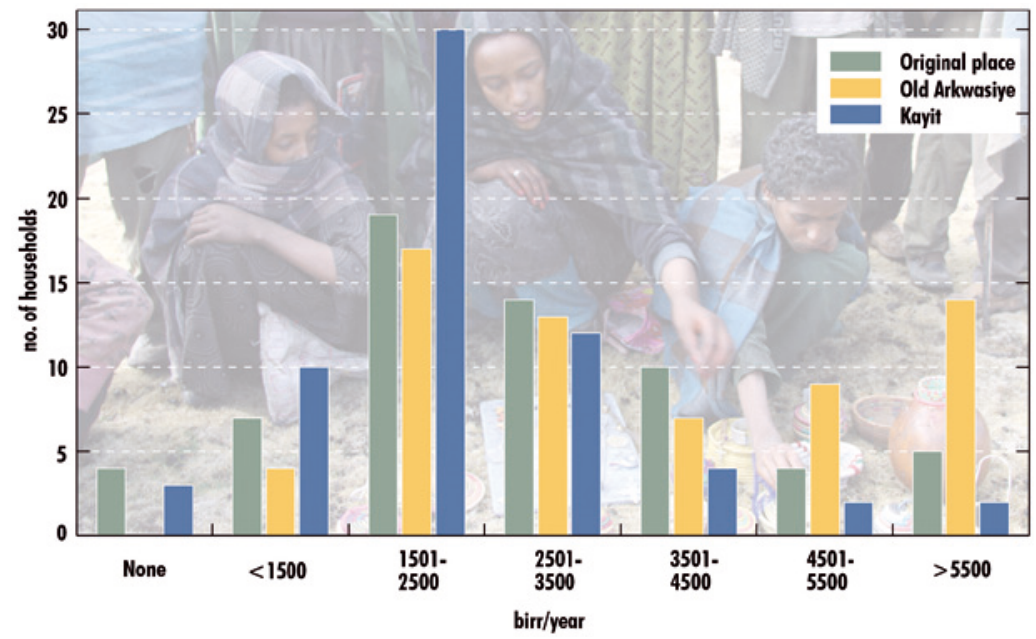

Figure 5 - Changes in household incomes (based on interviews in 64 bouseholds; Tiru 2011).

production were bartered. A few traders sold household items, spices or clothes (Hurni \& Ludi 2000). The first houses were built some 25 to 30 years ago during the violent conflicts in Northern Ethiopia. Owing to the favourable location between three weredas (municipalities), the place had attracted more and more new settlers from adjacent villages (Tiru 2011).

To prepare for the relocation of the inhabitants from Arkwasiye to Kayit (the new place), the national park management founded a committee in close collaboration with ADA (the Austrian development agency) and village representatives. A plan of action was prepared together with the residents and a compensation scheme was negotiated and agreed upon. The compensation became an incentive to facilitate voluntary relocation. In 2007 the relocation process took place. It was supervised by a technical committee established by the local government. Arkwasiye was dismantled (Tiru 2011).

\section{Economic effects}

Originally, Arkwasiye had been a temporary market place. With the economic opportunities this market place offered, it had attracted more and more people to settle permanently and thus the village grew. The interviews indicate clearly that settling in Arkwasiye went along with a change of jobs and income (Figure 4 and Figure 5). Most of the newcomers (65\%) had a farming background and developed new ways of making a living. Their activities expanded from just agriculture or livestock farming to various forms of trading and so they had more than one source of income (Figure 4). Arkwasiye, as desolate as it may have seemed from its outward appearance, had obviously become an economic promise of success to the surrounding rural population in that region.

Even though it is only two kilometres away, the relocation from Arkwasiye to Kayit seems to have considerably affected the income opportunities of the villagers. Most strikingly, a return to farming has become necessary to compensate for the loss of trade-related incomes (Figure 4). The inhabitants have therefore no other option but to return to their original activities. The statement of a man in his forties illustrates the changes caused by the relocation: "... at my original place, my occupation was farming, after I settled at Arkwasiye, I was engaged in farming and rural trading, but now ... I shifted to my early work - farming." (quotation by Tiru 2011; p. 43).

As a result of the shift in occupations, household incomes seem to have decreased significantly (Figure 5). The interviews demonstrate that the number of households with very small incomes of not more than 2500 birr per year (i.e. less than 150 USD) have doubled, whereas the number of households with relatively higher incomes have decreased. The average incomes are even lower than what they had been before the villagers left their original homes to settle in Arkwasiye. Although it may be argued that this finding is based only on interviews and may be biased by external factors (e.g. inflation) or intrinsic interests of the interviewees, the results do indeed seem to be sufficiently plausible. However, not all experts involved share this point of view (Moll 2012, oral comm.). It cannot be disputed, however, that the sources of income are minimal and clearly below the poverty line as defined by the World Bank (Ravallion et al. 2009).

\section{The social effects and living conditions}

The cultural and social effects on the communities as a result of relocation are a major concern (Dowie 2009). Cernea (2007) identifies eight major risks related to resettlement, such as landlessness, joblessness, homelessness, marginalization, food insecurity, increased morbidity and mortality, loss of access to common property and, last but not least, social disintegration. 
Not one of these consequences can be identified in the interviews. People still live in the same environment, at the same altitude and in the same cultural and social context. The interviews give no indication of any kind of relocation shock. Many respondents $(45 \%)$ even stated that the relationship with those who are responsible for the management of the park has developed positively, both through and since the relocation process. Only $18 \%$ of the interviewees stated that their attutide towards the park was less positive than it was before.

Arkwasiye did not have deep roots as it was a temporary village, i.e. it had always been a settlement with insufficient housing. Even the most basic infrastructures and services were either lacking altogether or were very poor. From this point of view, it is understandable that the perception of the interviewees is clearly positive, as they state that the newly built houses are of better quality, an elementary school and a local health post have been established and a well to supply water has been constructed and it functions. Even though the standard is very basic, the respondents repeatedly refer to the new elementary school, providing basic education for some 70 children. All of the respondents agree that the social services have substantially improved in the new village, especially with regard to the provision of water, education and health services. To what extent these upgraded services and infrastructures can contribute to a new level of welfare and empowerment cannot be validated yet.

However, an increase in the population could be an indication that this is not unlikely. The comparably good provision of social services in Kayit has attracted new settlers from the adjacent areas. Since it became established, the population of Kayit has increased notably by 55 families (260 persons). Even those who had not owned a house in Arkwasiye also received compensation, which enabled them to construct a new house in Kayit. This is an additional factor that accounts for the increase in the number of households. However, this does not fully explain the increase in the number of inhabitants. There is some evidence that the quality of the new health and education services has somewhat declined with the arrival of the newcomers because of the limited capacity of the institutions.

\section{The ecological effects}

Since there is no systematic monitoring of the ecological effects as yet, the ecologic evaluation can be based only on the observations of Tiru (2011). He states that the pressure on pasture land for grazing has increased, not only in the surroundings of Kayit but also in the surroundings of what was formerly Arkwasiye. Taking into account the results of the economic evaluation, these observations seem plausible. The increase in grazing pressure clearly contradicts the goals of the relocation (Debonnet et al. 2006). From

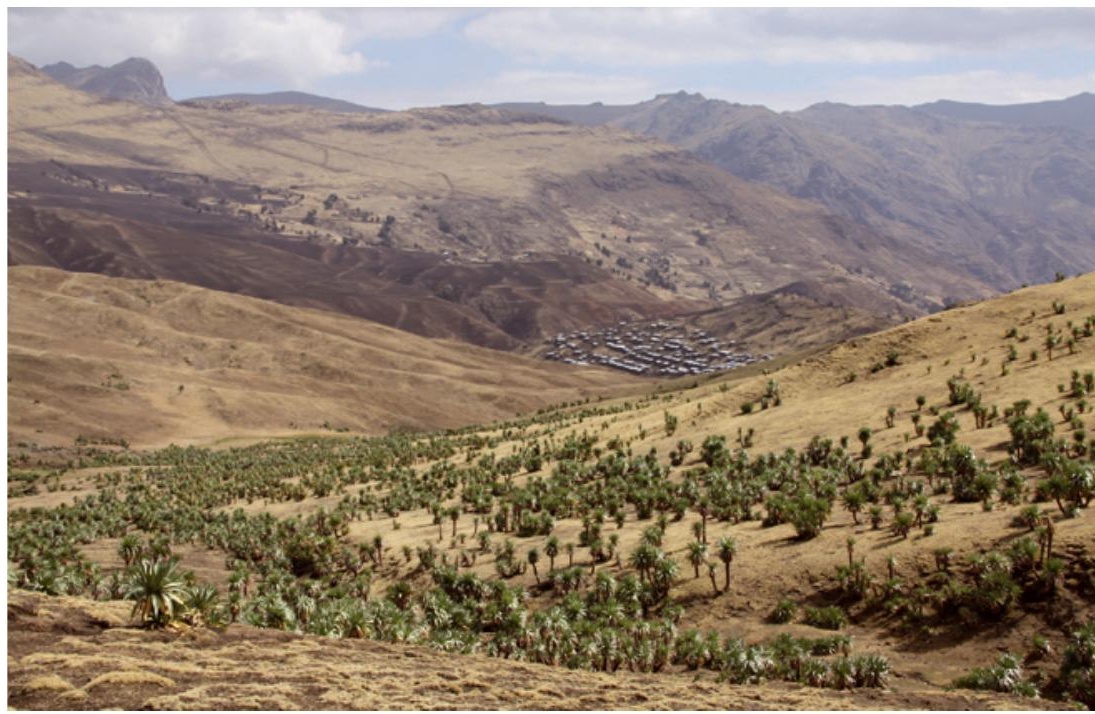

Figure 6-A new village for some 165 families: Kayit. (C) M. Jungmeier

a more general perspective, the UNESCO \& IUCN (2010) emphasize the fact that grazing is still an outstanding issue for the removal of the park from the list of endangered World Heritage Sites. However, a final evaluation of ecological effects cannot yet be given.

\section{Discussion}

Any kind of relocation in the context of conservation has come under critical debate. Schmidt-Soltau (2005) claims that it has become a common [sic] phenomenon, that people are sacrificed for the sake of biodiversity and wildlife. Summing up decades of experiences with the population displacement approach, Cernea \& Schmidt-Soltau (2003) argue that this strategy has exhausted its potential and its credibility. In Ethiopia relocation is a practice used repeatedly to serve different purposes, one of which is conservation (Biressu 2009; Dowie 2009). In a critical reflection of his investigation on resettlements for improving agricultural practices in Ethiopia, Walle et al. (2011) conclude by uttering a warning, To this end, when resettlement is an unavoidable means of securing food selfsufficiency, it should be minimized by investigation of all viable project options.

In comparison with the drastic statements and examples of evictions for conservation purposes, as presented by diverse authors (Cernea 2006; Cernea \& Schmidt-Soltau 2003; Dowie 2009; Lasgorceix \& Kothari 2009; Redford \& Fearn 2007; Schmidt-Soltau 2005), the process in SMNP was obviously professionally prepared and implemented in a considerate and tactful way. The fundamental right to be able to decide voluntarily to relocate was respected and this was confirmed by the villagers in the interviews as well as by the international institutions (e.g. Debonnet et al. 2006; UNESCO / IUCN 2009). The improvement of services and infrastructures, in addition to the compensation offered, made the idea to relocate attractive for the former residents of Arkwasiye. The increased appreciation shown to those who manage the park in- 


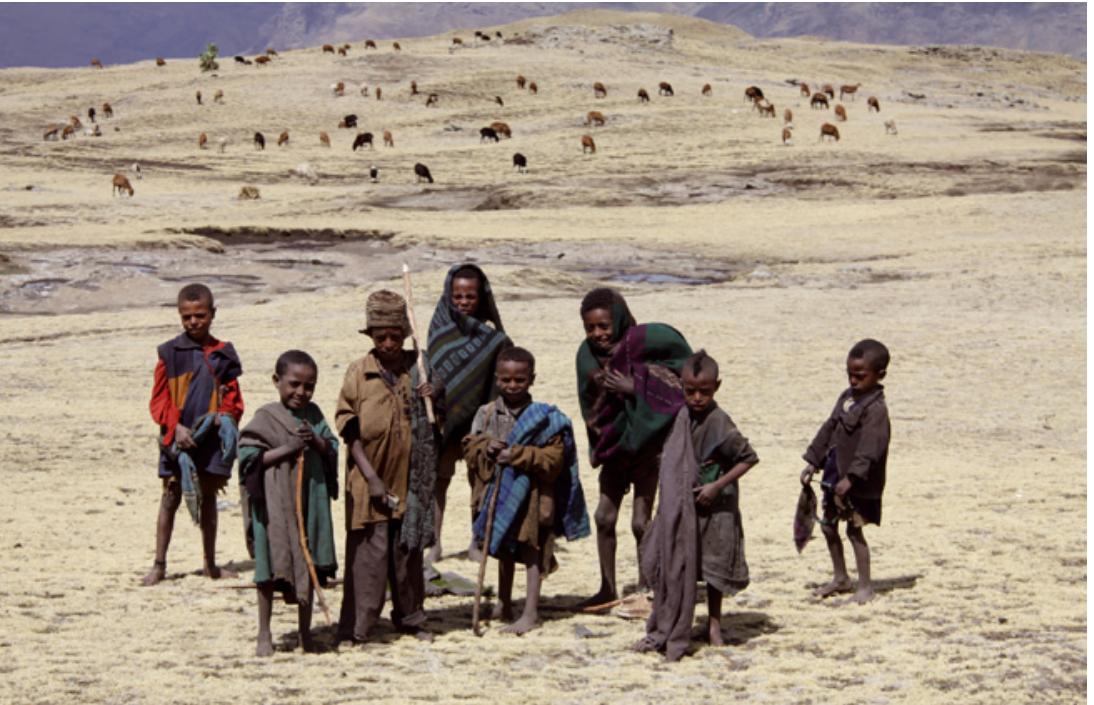

Figure 7 - Important asset in the livelihood of the Simien Mountains: livestock grazing at bigh altitudes. (C) M. Jungmeier

dicates that the process was performed and perceived in a positive way.

From a professional and technical point of view, the reasons for the relocation were understandable and made sense. Not only was the relocation an international prerequisite to securing the desired status of World Heritage Site, but the unplanned and uncontrolled sprawl of the settlement would have required some kind of intervention anyway. The removal of a considerable barrier in an important ecological corridor seems to be more than plausible (see Figure 2). Thus the intervention in the form of relocation was, nonetheless, a move towards a planned and well-regulated form of development for the future.

However, even well planned and implemented relocations may have some unexpected side-effects affecting local livelihoods (Dhakal 2006; McLean 1999). In the case of Arkwasiye, the relocation resulted in increasing grazing pressure, which had not been foreseen. The two main reasons for this unexpected outcome were the necessity of the local residents to return to farming and livestock breeding, and the fact that additional settlers were attracted to Kayit because of the new and improved infrastructure and services. This situation could have become clear in an ex-ante evaluation and been avoided by taking appropriate measures before the people were relocated.

The same applies with regard to the obvious loss of income. As they are no longer close to the most important eco-touristic infrastructure, the hiking trail to Ras Dashen and the traditional market place, it is and will be - more difficult for the villagers to develop complementary and alternative sources of earning in addition to their agricultural incomes. None of the interviews pointed to any future perspectives. These results suggest that a post-relocation development initiative is essential. Dhakal (2006) describes mechanisms and results of such an initiative by referring to Chitwan National Park (Nepal) as an example and he points out how important the role of the NGOs is in such a process. To find a solution to the issue of livestock-farming, it must be treated in a broader context (Hurni \& Ludi 2000; Grünenfelder 2005).

Hence, a final appraisal of the relocation of Arkwasiye village cannot be given yet. Since the relocation of Arkwasiye is meant to be a prototype for one or two further relocations from the park, for instance the village of Gich, the authors make the following suggestions for similar operations:

Basically, relocations are always problematic for the social, economic and ecological systems.

The fundamental right to be free to make voluntary decisions and to participate are indispensable prerequisites.

Ex-ante and ex-post evaluations with all stakeholders are required.

The post-relocation measures need to be carefully prepared and financially secured.

A systematic monitoring of key parameters must document the process for at least 20 years.

On principle, a long-term view must be taken of any intervention in the management of a national park and needs to be questioned against the concepts of pro-poor conservation (Roe et al. 2003). For the SMNP, Hurni \& Ludi (2000) envisage moderate modernization as a suitable way to improve livelihoods, remove vulnerability, reduce degradation and preserve a globally important World Heritage Site.

\section{Acknowledgements}

The authors want to express their gratitude to Leonhard Moll, ADA (formerly in Addis Abbeba, now in Palestine), to Ato Tessome Mulu (ADA's SMNP Integrated Development Project) and to Alexandros $\mathrm{Ma}-$ karigakis, UNESCO Office Addis Abeba. The study was made possible by an ADA / ÖAD scholarship and the kind support of the Austrian National Committee for the UNESCO Man and the Biosphere Programme at the Austrian Academy of the Sciences. Our thanks are also due to Peter Rupitisch for providing the photographs and to Elisabeth Kreimer for the graphics, as well as to Günter Köck, Christina Pichler-Koban and Elizabeth Enfield, all of whom contributed to the critical revision of this paper.

\section{References}

Biresu, A.N. 2009. Resettlement and Local Livelihoods in Nechsar National Park, Southern Ethiopia. Master Thesis of Philosophy in Indigenous Studies. University of Tromsø. Norway.

Cernea, M. 2006. Population Displacement inside Protected Areas: a Redefinition of Concepts in Conservation Policies. Policy Matters 14: 8-26.

Cernea, M. 2007. Impoverishment Risks, Risk Management, and Reconstruction: A model for Population Displacement and Resettlement. UN Symposium Beijiing. Oct. 2007. 
Cernea, M. \& K. Schmidt-Soltau 2003. National Parks and Poverty risks: Is population resettlement the solution? Available at: http://www.schmidt-soltau.de/english/ (accessed 19/09/2012)

Coad, L., A. Campbell, L. Miles \& K. Humphries 2008. The Costs and Benefits of Protected Areas for Local Livelihoods: a review of the current literature. Working Paper. UNEP / WCMC. Cambridge.

Dhakal N.P, K.C. Nelson \& S.L. Smith (eds.) 2006. Assessment of Resident Wellbeing and Perceived Biodiversity Impacts in the Padampur Resettlement, Royal Chitwan $\mathrm{Na}$ tional Park, Nepal. University of Minnesota.

Dowie, M. 2009. Conservation refugees. The Hundredyear Conflict between Global Conservation and Native Peoples.

Debonnet, G., Melamari, L. \& B. Bomhard 2006. Reactive Monitoring Mission to Simien Mountains National Park. Ethiopia. 10 - 17 May 2006. IUCN. UNESCO.

Gebreyes, K.A. \& M. Jungmeier 2010. Biosphere Reserves in Ethiopia - Preliminary Study. Unpublished report, commissioned by MAB - Committee of the Austrian Academy of the Sciences.

Grünenfelder, J. 2005. Livestock in the Simien Mountains, Ethiopia. Its role for the livelihoods and land use of local smallholders. Master Thesis submitted to the Faculty of Natural Sciences of the University of Berne.

Hurni, H. \& E. Ludi 2000. Reconciling Conservation with Sustainable Development. A Participatory Study Inside and around the Simen Mountains National Park, Ethiopia. Centre for Development and Environment (CDE). University of Berne. Bern.

Institute of Biodiversity Conservation 2009. Convention on Biological Diversity (CBD) Ethiopia's $4^{\text {th }}$ Country Report. Addis Ababa.

Jungmeier, M., I. Paul-Horn, D. Zollner, F. Borsdorf, S. Lange, B. Reutz-Hornsteiner, K. Grasenick, D. Rossmann, R. Moser \& C. Diry 2009. Part_b: Partizipationsprozesse in Biosphärenparks - Interventionstheorie, Strategieanalyse und Prozessethik am Beispiel vom Biosphärenpark Wienerwald, Großes Walsertal und Nationalpark Nockberge - Band I: Zentrale Ergebnisse. Österreichisches MABNationalkomitee. Österreichische Akademie der Wissenschaften. Vienna.

Lasgorceix, A. \& A. Kothari 2009. Displacements and Relocations of Protected Areas: A Synthesis and Analysis of Case Studies. Economic \& Political Weekly 49: 37-47.

Keiner, M. 2001. Towards a New Management Plan for the Simien Mountain National Park. Walia 21/2000: 14 24. Addis Abeba.

McLean, J. 1999. Conservation and the Impact of Relocation on the Tharus of Chitwan, Nepal. Himalayan Research Bulletin 19(2): 38-44.

Mittermeier, R.A., P.R. Gil, M. Hoffmann, J. Pilgrim, T. Brooks, C.G. Mittermeier, J. Lamoreux \& G.A.B. da Fonseca 2004. Hotspots revisited: Earth's biologically richest and most endangered terrestrial ecoregions. Conservation International. Chicago.

OeBF 2009. Assessment of the Value of the Protected Area System of Ethiopia "Making the Economic Case".
Study report in the frame of the SDPASE-Project of the Ethiopian Wildlife Conservation Authority. 3 Volumes. Vienna.

Puff, C. \& S. Nemomissa 2005. Plants of the Simen. A flora of the Simen Mountains and surroundings, northern Ethiopia. Scripta Botanica Belgica 37.

Ravallion, M., C. Shaohua \& S. Prem 2009. Dollar a day. The World Bank Economic Review 23 (2): 163-184.

Redford, K.H. \& E. Fearn (eds.) 2007. Protected Areas and Human Displacement: a Conservation Perspective. WCS Working Paper 29.

Roe, D., J. Hutton, J. Elliott, M. Saruchera \& K. Chitepo 2003. In Pursuit of Pro-poor ConservationChanging Narratives... or More? Policy Matter 12: 87-91.

Schmidt-Soltau, K. 2003. Conservation Related Resettlement in Central Africa, Environment and Social Risks. Development and Change 34 (3): 525-551.

Schmidt-Soltau, K. 2005. A roadmap to sustainability: Learning from the mistakes of conservation- and developmentinduced involuntary displacements in Central Africa. Available at: http://www.schmidt-soltau.de/english/ (accessed 20/09/12)

Tiru, B.T. 2011. Social, Economic and Ecological Effects of Relocation Arkwassiye Village from Simien Mountain National Park, Ethiopia. Master Thesis, University of Klagenfurt.

UNESCO/IUCN 2009. Aide Memorie on the Joint UNESCO/IUCN reactive monitoring mission to the Simien Mountains National Park World Heritage Site, Ethiopia. Unpublished protocol. Addis Abbeba.

USAID 2008. Ethiopia Biodiversity and Tropical Forests. 118/119 Assessment.

Walle, T., S. Rangsipaht \& W. Chanprasert 2011. Natural Resource Conservation Practices of Resettlers in the New Resettlement Areas of Amhara Region, Ethiopia. Kasetsart Journal Social Science 32: 297-307.

\section{Acronyms and abbreviations}

ADA: Austrian Development Agency

IUCN: International Union for Conservation of $\mathrm{Na}-$ ture

UNESCO: United Nations Educational Scientific and Cultural Organization

WHS: World Heritage Site

SMNP: Simien Mountains National Park

\section{Authors}

\section{Tiru Berihun Tessema}

Born in 1963, he has an education in business administration and is a graduate of the MSc programme Management of Protected Areas at Klagenfurt University. He works for the Amhara Regional Government State, North Gondar Zone, Gondar, Ethiopia; email: beri-hun.tiru@yahoo.com 
Michael Jungmeier

Born in 1965, the biologist and human geographer runs the MSc programme Management of Protected Areas at the Institute of Economics, University of Klagenfurt. He is C.E.O. of E.C.O., a consultancy specializing in protected areas, 9020 Klagenfurt, Austria;

email: jungmeier@e-c-o.at. Corresponding author

Michael Huber

Born in 1983, the landscape planner is project manager at E.C.O., Institute of Ecology, 9020 Klagenfurt, Austria;

email: huber@e-c-o.at. 